\title{
LEARNING BIOGRAPHIES IN A EUROPEAN SPACE FOR SOCIAL MEDIATION
}

\author{
Rob Evans
}

\begin{abstract}
Within the framework of a European Erasmus+ project, trainee mediators were interviewed about their experience. The encounters took place in unstructured, in-depth qualitative biographical-narrative interviews, in which individuals who are engaged in dialogic interaction create shared understanding and give meaning to their stories. The interview is interactive, coconstructed. The detail of the interview language documents how meaning-making takes place, and how this is affected by group belonging, ethnic or cultural discourses, as well as gender, age, professional and educational relationships, and so on. The interview is sensitive to language resources and their use in the co-construction of meaning. This paper, using extracts from one biographical narrative, shows that the languaged form that these narratives of the biographical learning of mediators take can offer insight into the learning processes triggered by learning in communities of practice, and that the creation of a common space of experience can be heard as it emerges in biographical talk. Biographical resources, biographicity, and their relationship with language and society are considered, and in the interview narratives the creation of a learning space, a space for the development and unfolding of notions and practices of mediation can be observed, heard and shared.
\end{abstract}

\section{BIOGRAFIAS DE APRENDIZAGEM NUM ESPAÇO EUROPEU DE MEDIAÇÃO SOCIAL}

\begin{abstract}
RESUMO
Dentro da estrutura de um projeto Erasmus+ europeu, foram entrevistados mediadores estagiários sobre a sua experiência. Os contactos realizaram-se através de entrevistas não estruturadas, biográfico-narrativas qualitativamente profundas, nas quais indivíduos comprometidos com a interação dialógica criaram um entendimento partilhado, dando significado às suas histórias. Trata-se de entrevistas interativas, co-construídas. $O$ detalhe da linguagem da entrevista documenta como a construção do significado ocorre, e como esta é afetada por motivos de pertença a determinados grupos, por discursos sobre etnias e culturas, assim como pelo género, idade, relações profissionais e educacionais, entre outros. A entrevista é sensível aos recursos da linguagem e aos seus usos na co-construção do significado. Este artigo, usando excertos de uma narrativa biográfica, mostra que a forma falante destas narrativas da aprendizagem biográfica dos mediadores pode oferecer uma visão do processo do conhecimento despoletado pela aprendizagem em comunidades de práticas, e que a criação de um espaço comum de experiência pode ser ouvido na conversa biográfica. Os recursos biográficos, a biograficidade e a sua relação com a linguagem e sociedade são considerados e, nas narrativas da entrevista podem ser observadas, ouvidas e partilhadas a criação de um espaço de aprendizagem, um espaço para o desenvolvimento e a revelação de noções e práticas de mediação.
\end{abstract}


PaLAVRas-Chave

Entrevista biográfico-narrativa; construção de sentido; co-construção; biograficidade; savoir-vivre; mediação

\section{INTRODUCTION}

The original call for papers for the international conference organised by colleagues in the Institute of Education and the Social Sciences Institute at the University of Minho in Braga, invited contributions touching on migration, diversity, intercultural communication and the contribution of mediation to the promotion of an open, inclusive, safe and peaceful civil society. In response to the call, this paper attempts to examine the learning biographies of practitioners of social mediation participating in the three-year (20172019) ERASMUS+ project CreE-A (Construction d'un espace européen de la Médiation sociale pour l'inclusion)' in order to discuss the contribution that biographical narrative can make to an understanding of the formation of mediator identity and practice.

The CreE-Arlekin project has as its ultimate and highly ambitious objective the creation of a professional community for social mediation in Europe. A European consortium involving different partners, which include organizations for mediation and training, universities, cities, individual experts for mediation theory and praxis, as well as representatives from national as well as European politics, work together in the project to establish a structured interchange between the theory and practice of European mediation. The short and middle-term objective of CreE-A is to identify common practices of social mediation, and to promote awareness and knowledge of these practices while respecting the diversity of its realization in the specific contexts of each country (Silva, Carvalho, Moisan \& Fortecöef, 2017).

The core feature of the project is the Tour d' Europe, a journey of experiential learning modelled on the journeyman traditions of European artisans. In 2017, the first year of the current project, 14 practitioner mediators (or professionals from mediation-near practices) were sent from country to country around the seven participating countries on a "journey of immersion in the realities of mediators' work", participating reflexively in a "journey through Europe, during which each participant knew and shared biographical and professional experiences, as a mediator with other Practitioner-Mediators of different countries" (Silva et al., 2017, p. 75). Each participant brought with them prior practitioner experience and knowledge and each was confronted in their period of immersion with fellow mediators who received them and provided them with a learning space in which different practices could be compared and confronted, and in which diverse learning biographies interacted and knowledge, both formal and tacit, could be exchanged.

Parallel to their practical immersion in the reality of the mediation practices of their peers, the participants were required to reflect on their personal and professional biographies. Reflective tools were provided them by the project coordinators to help them identify diverse professional experience and knowledge, to sharpen their awareness of 
practices of mediation for social inclusion in the host country, to observe and describe the mediation practices encountered and to report on this in the form of a multimedia report to successfully complete their participation in the project (the Chef d'Oeuvre Masterpiece - Meisterstück) which was adjudicated by a Jury of Experts at the end of 2017 in Barcelona.

\section{THE RESEARCH: INVESTIGATING A BIOGRAPHY OF LEARNING}

During the final seminar in Barcelona, eight of the participants (five practitioner mediators and three expert mediators) were interviewed about their experience during the Tour d' Europe and the impact of the European space for social mediation as they lived it during their immersion in the host country. The encounters with the participant-mediators took place in unstructured, in-depth qualitative biographical-narrative interviews, in which individuals who are engaged in dialogic interaction create shared understanding and give meaning to their stories. Their narrative histories are made understandable, to cite Luckmann, by the joint process of "experiencing othered-experience" (Luckmann, 1981 , p. 58). The interview is interactive, co-constructed, and made up of voices, the voices of the co-researchers and of others whose words are employed and recalled by the speakers. The detail of the interview talk documents how meaning-making takes place, and how this is affected by group belonging, ethnic or cultural discourses (Pavlenko, 2007), as well as gender, age, professional and educational relationships, and so on. The interview is sensitive to language resources and their use in the co-construction of meaning, and as such it was only logical to conduct the Barcelona interviews in the languages of the participants themselves, namely French, Italian, Portuguese and German.

In this paper, using extracts from one biographical narrative, I will try to show that the languaged form that these narratives of the biographical learning of mediators take can offer insight into the learning processes triggered by learning in communities of practice, and that the creation of a common space of experience can be heard as it emerges in biographical talk. The paper is constructed as follows:

- first, I shall consider some of the conditions necessary for any discussion of spoken language and its use as "data". In particular it is necessary to establish a certain caution in relation to the use of transcripts based on multilingual interview talk;

- second, biographical resources and their relationship with language and society from the standpoint of inter-subjectivity and of language as action will be considered;

- third, this will be followed by a brief discussion of biographicity and the relevance of language data which is produced in the biographical narrative will be examined;

- finally, my concluding remarks will seek to underline the advantages of the language approach discussed here in throwing light on the ongoing learning process recounted in life history narratives of mediators. The creation of a learning space, a space for the development and unfolding of notions and practices of mediation can be observed, heard and shared;

- the talk of one of the mediators interviewed in Barcelona in 2017, Butoyi (name changed for anonymity), will be drawn on selectively throughout. 


\section{USING QUALITATIVE INTERVIEWING TO UNDERSTAND THE MEDIATOR}

The qualitative research interview engages with individual and group experience of social reality and observes, questions and records the testimony of the actors themselves in sites of social interaction chosen for the collection of data and its subsequent analysis. The relationship between social actors who are involved in processes of transition and transformation in very different social, professional, personal contexts and the researcher has been central to the discussion of research methods and research aims throughout the various methodological "turns" of the last decades (Merrill \& West, 2009).

There are a number of different approaches to the biographic interview and narratives centred on life-stories. As indicated above, I propose in the following the use of the discursive-biographic interview, which focuses on languaged meaning-making in the interactive discourse of biographical narratives. Other areas of biography and life history research must necessarily be excluded from this short discussion, though their theoretical and empirical value is not in question (see for example Alheit, 2002; Bertaux, 2005; Dausien, 1996; Demetrio, 1995; Fuchs-Heinritz, 2000; Merrill \& West, 2009; Pineau \& Le Grand, 2007; Schütze, 1976, 1981)

Research interview respondents participating in diverse life worlds, such as the practicing mediators interviewed in Barcelona, provide insight in unstructured discursive interviews into the significance of critical change processes for their individual and collective learning. In so doing, I argue here, they can be heard building own discourses of learning, in which acceptance of, and resistance to, the dominant discourses of institutions and civil society is laid down in the interdiscursive layering of interaction with (a) the own told narrative, (b) with the researcher agenda and (c) in the all-important dialogue with those significant others whose voices and narratives give expression to the complexity and transacted meanings of individual and group learning contexts. The mediator brings to their work and to their talk a personal history, a family history, a history of learning and a history of life-choices, to name but a handful of the critical steps in the development of an individual.

\section{BIOGRAPHICAL TALK, TRANSCRIPTION, TRANSLATION AND PRESENTATION}

Before moving to an examination of parts of the narrative analysed here, some words on the use of interview transcripts in biography research are necessary. It is widely acknowledged that the decision for a particular level of detail in the reproduction of the spoken interview or the omission of detail represents the fundamental level of analysis decided for (Gülich \& Mondada, 2008; Ochs, 1979). Likewise, the analysis of timing, volume, intonation, stress, and prosody, which are understood to be essential products and producers of interaction and co-construction of meaning (Günthner, 1997; Szczepek Reed, 2011).

Presentation of the data and the findings presents some interesting hurdles to surmount. Given the technical difficulties of presenting different interview languages in a word-for-word type translation on account of radically different syntactical structure, and 
embedded morphological problems, not to mention the problematic nature of exemplifying features of meaning and discourse by recourse to de-contextualised translations, as a rule, translation is employed exclusively in order to provide access to the discussion of different language discourse phenomena. Any attempts to render the prosodic elements of discourse must in this sense always be understood as performing a strictly impressionistic function. In this paper, the extracts of talk presented are left in the original French. Commentary and discussion of the interview talk always refers to the original language.

As for the transcription/presentation of the talk, the demands of faithfulness to the original language of the interaction and therefore to the intercultural pragmatics of the reception process and the explication of the results of data analysis must be attended to in research of this kind. Aneta Pavlenko (2007) has pointed out that when working with multilingual interviewees or working in more than one language, whether in the interview process or in the post-production process of presentation and dissemination, the full picture of the linguistic richness of the narrative and the full implications of working in one language or another must be taken seriously (Pavlenko, 2007).

For this reason, it is necessary to explain briefly the method employed here to present speech and the basic transcript format. Regarding the question of colloquiality versus any type of "ideal" representation of speech, I opt here for a transcription that ignores individual pronunciation or natural elision, providing an orthographically "regular" version of the talk heard. On the other hand, every form of written-standard punctuation is omitted as being foreign to speech. In its place there are indications of rising or falling intonation (? and _), pauses, breathing (inbreaths .h and outbreaths h), loudness (in CAPITALS), etc. No attempt is made, either, to force the talk into any kind of 'shape', in the form of paragraphs, or by using colons, dashes, or any other form of logical organization. Short pauses are indicated by (.), longer pauses are loosely timed in seconds (2.0). Hesitation or filling is indicated as "uhh". Unintelligible passages of the interview recording are marked as (xxx).

Every transcription extract (TS) is presented in French in the form of a table, as follows.

\begin{tabular}{lll}
\hline $\begin{array}{l}\text { Extract } \\
\text { line no. }\end{array}$ & French TS & Commentary on narrative structure and interactive work \\
\hline
\end{tabular}

Table 1: Presentation of transcript excerpts

Column 1 shows the line number within the current extract. Column 2 contains the original French TS. Column 3 contains information relevant to the analysis of the TS as narrative. Thus, for instance, this column may contain references to information about discourse features (e.g. epistemic discourse $(\rightarrow$ EpD), prosody $(\rightarrow$ Pro) modality $(\rightarrow M P)$ or self-repair or hedging ("self-repair" $\rightarrow$ SR). Column 3 may also contain turn information, where specific turns or moves are highlighted and discussed in the analysis. Of particular importance in this understanding of the voiced nature of biographical discourse is the reference to "embedded speech" (ESp). 
Linde points out how other peoples' stories (related in reported speech, embedded and 'layered' in the telling) become "own" stories through a process of appropriation or conversion (Linde, 1993, p. 35). The discontinuous and unfinished state of the oral narrative is embodied therefore in the discourse employed by the autobiographical narrator. Here Goffman's concept of "embedding" can be used to describe this aspect of the speaker's "self". The words we speak, he points out, "are often not our own, at least our current "own"" for "although who speaks is situationally circumscribed, in whose name words are spoken is certainly not" (Goffman, 1981, p. 3). Thus, embedding makes it possible to 'enact' numerous voices over space and time within the interactive frame of the oral narrative and narrative interview (Goffman, 1981, p. 4). This, as I shall try to show in the data analysis further on, is a central feature of interactive talk in the research interview. Indeed, for the development of "own" discourses within an emergent learning biography, the "converted" and "enacted" words of others or a non-current "self" - what I call here "embedded speech" - are an important device for contextualization of talk and serve as a device for grounding the validity of the talk, giving it authority (Evans, 2004).

\section{BIOGRAPHICAL RESOURCES: LANGUAGE AND INTERSUBJECTIVITY, LANGUAGE AND “THE WORLD”}

Biographical experience is connected at all times to a specific context, and new experience is worked and reworked into the former life story. "Biographical experiences and the biographical knowledge that arises from them", then, as Hoerning points out, "are not merely the laying down of a stratum of things experienced but also the continuous re-working of all that is experienced" (Hoerning, 1989, p. 154). The biographies narrated across encounters are discontinuous pieces, and the talk, as we shall see further on, is biographized talk, which is structured both temporally and sequentially, performing in interactive communication the re-working of experience that Hoerning is concerned with. Ochs and Capps express it thus: "personal narrative is a way of using language or another symbolic system to imbue life events with a temporal and logical order, to demystify them and establish coherence across past, present, and as yet unrealized experience" (2001, p. 2).

The "sea change" of the "linguistic turn" from the 1960 s towards interest in an "unfolding, socially coordinated, temporally and spatially situated" understanding of language-mediated practices, activities and action (Schegloff, Ochs \& Thompson, 1996, p. 6) furthered the notion of investigating joint and collective construction of meaning through intersubjective communication in which the perspective of the research subject was foregrounded (Hoffmann-Riem, 1994; Schiffrin, 2006; Schütze, 1975). The accomplishment of meaning in the interplay of interactive contexts (social, institutional, physical, or emotional, and so on) is achieved in this view of things through the sequential unfolding of the interactive resources of members of diverse settings in discourse "with others beyond themselves, ultimately with the world" (Ricoeur, 1995, p. 41). The wider contexts in which participants are active are understood here as, in Gale Miller's words, interconnected "ecologies of knowledge" in which situation-specific interactional 
meanings are organized (Miller, 1994, p. 168). According to this view of things, subjects are able to make use of the resources of different, socially organized settings to which they belong (or to which they are positioned as belonging, for example) in order to discursively constitute and reconstitute themselves and the institutional settings in which they interact.

Discursive processes of identity construction, then, are situated in language interaction at many, at multiple, levels. Interaction and relations of reciprocity between individual subjects and others provide the framework within which "selves" are constructed in communication with others. The changing relationship of individual subjects to their own and others' words, current or long-past, influence identity construction at every step. The language available in many ways to individuals permits them to describe themselves and the world, and the relationships of membership within (and dissociation from) recognisable groups. Different relationships of membership and belonging to place, to an ethnic group, to socially accepted or socially stigmatized groups - a profession much respected, a ghetto community, a religious community - are constructed in talk through indexicality. In this way, "situated" or global identities which intersect constantly in the discourse of speakers are created (De Fina, Schiffrin \& Bamberg, 2006).

Silva, Carvalho and Aparicio (2016) point out that the formation of professional mediators is a process involving interaction with others, with the social context of the action of mediation, as well as a process of reflection and action by the individual on herself in the process of her formation. The becoming process is, they claim, "a dynamic, interactive, contextualized and continuous construction process". Further, in agreement with a large body of literature, they argue that it is an

individual process in which the image and definition of oneself (history and personal identity) and of others (social identity) are configured in relation to the recognition (points of reference, membership, attributes, identifications, collective status) granted by other members of the professional family. (Silva, Carvalho \& Aparicio, 2016, p. 94)

Thus, subjects make use of their biographical resources formed in social action in order to discursively constitute themselves and the personal and professional contexts they interact in with others. Butoyi, the project participant whose talk will be considered now, provides evidence of this element of the life history.

She was asked to talk about her education and choice of studies. Asked why she chose to study law, Butoyi replies:

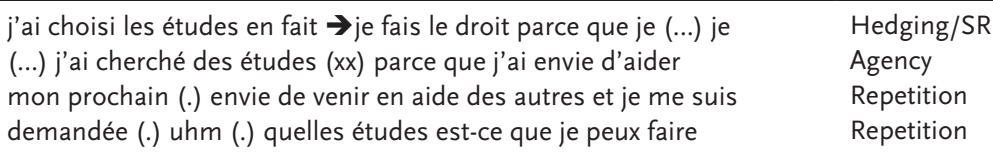


She thinks, delays cautiously her reply (indicated as hedged speech/self-repair in I.1) and then formulates a strong first-person claim, employing heavy repetition ("envie d'aider"; "venir en aide"; "pour aider"; II. 2-4). Given the emphasis with which she evidently wishes to underline the desire to help, she is asked why she chose law in order to help others. Butoyi states that she was looking for something different to that practiced already by her mother (a nurse) and her sisters: “j'ai cherché quelque chose de différent pour ne pas faire la même chose ...".

She continues:

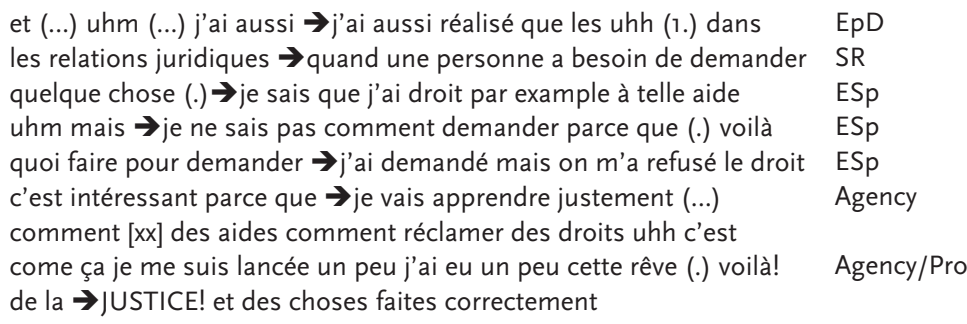

Table 3: Extract 2

Butoyi slips in her narrative into the guise and voice of an anonymous Other. Her wish is clearly to express and justify her dissatisfaction with ordinary, everyday "legal matters". Someone in need of legal aid or information often finds themselves blocked or refused by the usual routines of the law, she argues. Butoyi's knowledge claim is given a voice from "off-stage" (indicated as ESp), a voice in the first person, an immediate claim of veracity and urgency. This use of the embedded speech of an Unknown Other, serves here to justify the hesitant, hedged advancement of Butoyi's own standpoint. It is "Justice" she wishes to see. The emotive straightforwardness of Justice is carefully paraphrased: to see "things done correctly". Emphatic prosodic language, harnessing energy and volume, is framed thus by heightened fiction-like detail and consciously sober rhetoric. Butoyi employs the contexts of her experience in a natural and skillful manner to construct a tellable message, rendering her narrative meaningful and shareable.

Butoyi's family background plays a role in the values she expresses. Her grandfather was a school director in Burundi. The experience of immigration, of arriving in Belgium, was not without significant difficulties.

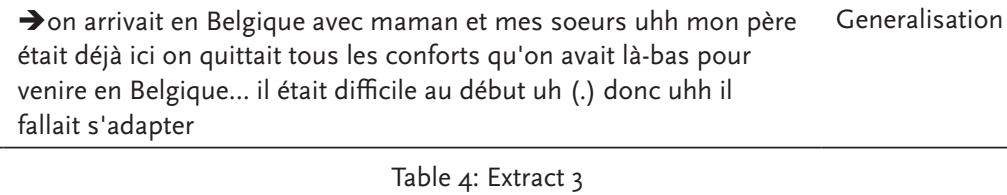

Table 4: Extract 3

Butoyi remarks that her nieces today are free of care by comparison. Their parents gave them all they could. For her own part, and that of her family, the adjustment was 
more difficult initially. Under the pressure of the new, foreign environment in Belgium, "on a dû readapter ici, refaire les études". This pressure on the young members of the family meant that "on mature un peu plus rapidement". Faced with decisions forced upon them by the context in which they were constrained to 'grow up quickly', Butoyi says, "on réflechissait, on a dû réflechir un peu plus vite que les autres".

In these remarks, the repeated use of the impersonal pronoun is clearly noticeable. This allows the speaker to recede into the background. The general, the generalised experience of her family is proposed and is foregrounded. The epistemic narrative is thus generalised. Further, with "fallait s'adapter", and "a dû readapter" we are given to understand that the family, Butoyi herself, were constrained by the force of circumstance. The forced loss of agency, it seems, is more than made up for by the agentic act of selfassertion and the knowledge claims Butoyi seeks to establish.

Not only are we given here the relation of a generalised valid truth, but we can already within only a few seconds of talk begin to hear the power of repetition ("un peu plus", "on a dû readapter", "on réflechissait", "on a dû réflechir") that fashions talk rhetorically so powerfully (Tannen, 2007, p. 9).

This helps to justify the sense of insecurity that is stated, it colours the narrative with elements of force, necessity, but resilience, too. Butoyi goes on to relate with enthusiasm the story of how she was given the responsibility at the age of 12-13 of getting in the shopping for her family when her mother was at work. What, she suggests, is considered a scandal for many, she experienced as a source of strength, resilience and maturity. This short piece of narrative is initiated with "je me souviens" (I remember). She completes the discrete story with the words "moi, j'aimais bien cette autonomie là". Notably at this point in the narrative, Butoyi emerges vigorously in her narrative from the use of "on" to narrate as first person.

\section{BIOGRAPHICAL RESOURCES AND EVERYDAY FRAMES OF EXPERIENCE IN THE LIFE HISTORY}

The biographical method therefore allows us to ask how change in people's environments is recognized subjectively by individuals, and how such change influences learning in life/work/learning situations. Life stories, according to Alheit (1983), are essentially occupied with the necessity to synchronise disparate levels of experienced time: primarily, the dimensions of events and experiences framed as routine, every day, and those which operate on the life-time scale/horizon, which "links long past events with past experiences, past with present experience and ultimately present with conceivable future events" (Alheit, 1983, p. 189). To re-work the reserve of experiences with the newly experienced and bring about new associations between the new and the already lived means that the narrator draws on their collected and layered biographical resources. These resources we can think of as the individual sum or distillation of many different learning processes. They are the result of the individual meaning given to experience which produces subjective forms of knowledge. This knowledge in its turn is the basis of new cultural and social structures of experience. This social practice of accessing 
(and constructing) life-wide biographical resources in order to meet the everyday requirements of a more individually steered life-course has been called 'biographicity' (Alheit, 1990, 2018; Alheit \& Dausien, 2002).

We have already seen how Butoyi speaks of her childhood and youth in terms of autonomy and responsibility. Her studies are characterised throughout her narrative as a search for a purpose. At 16 or 17 she made the acquaintance of a woman who was a judge. Butoyi's desire to "help others" led her to study law for three years. But her studies remain dissatisfying. In her third year of undergraduate law studies she was introduced to mediation in the courts. Here she experienced the confrontation of the accused with the victims of their transgressions and the responsibilization of the accused, inducing a consciousness of the infraction they are accused of. Her reaction:

Table 5: Extract 4

Butoyi reproduces what she presents as her genuine spontaneous thought processes in this past moment. This immediacy renders the position taken up less assailable as it is not presented as a logical argument, or as a turn in a dialogue (with anyone). As such, this quite common use of embedded speech (ESp) is employed in order to set the narrator's own agenda and serves also to support the following epistemic claim, namely, that with the right intervention an offender - generalised as l'homme - will not repeat the offence. She criticises the legal system, however, as she saw how immediate remedy was replaced often by legal obscurities with the loss of dialogue or interaction between the "accused" and the "victim". Yet she thought she could see the potential in the use of such "win-win" mediation:

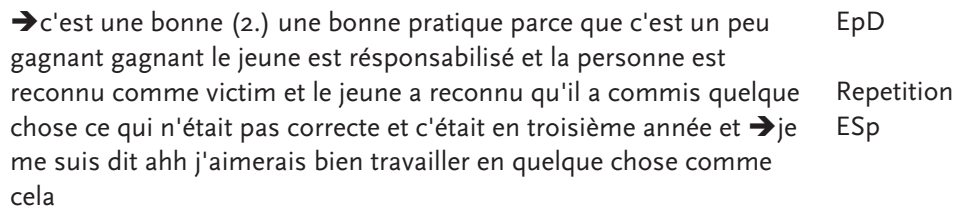

Table 6: Extract 5

Once again, in these short extracts from her detailed narrative of finding her rather circuitous way to her present engagement with mediation practices, it is clear at the simplest level of hearing how she constructs "chains" of narrative discourse, in which discourse claims with epistemic character ("c'est une bonne manière intéressante d'aider l'autre parce que" I.1-2; "c'est une bonne pratique parce que" I.3) are repeated with slight variations, following, however, very firmly fixed syntactical forms. The overall effect of the syntax in such passages of talk is voluntarily simple, employing single active verbs, produced in list-like progressions. This aids coherence; the statements are built up sequentially and cumulatively. The aim is seemingly to assert a certainty, guarding against 
possible criticism. The overall effect is crowned with - or leads up to - the marked use of embedded speech (Extract 4 l.1, Extract 5 l.4-5). Butoyi switches effortlessly from a confident type of epistemic discourse in which she states her approval of mediation in the courts, to the "brainstorm" effect this had on her own thinking: "je me suis dit ahh? j'aimerais bien travailler en quelque chose comme cela?" Butoyi is rendering once again her thoughts from that time in the past in the form of direct inner speech to lend them force and dramatic immediacy in the knowledge claim she is making in this moment about the value of mediation (and thereby about the "rightness" or "logic" of her present trajectory at the time of speaking).

Just as Butoyi here is doing, talking about places, times and events connected to each other in her past, Daniel Bertaux argues that "there is a life-history as soon as someone tells someone else, whether it is a researcher or not, any episode from their lived experience" (Bertaux, 2005, p. 36), because the discursive account takes on a form which is relatively spontaneous and dialogical (Bertaux, 2005).

Order and a certain coherence are voiced and constructed in narratives supported by 'grammars' of told experience. These - recurring stories, repeated use of language, for instance - are used to build the theories of events that emerge as ongoing effective negative or positive biographies (Capps \& Ochs, 1995). Lisa Capps and Elinor Ochs use the term "grammar" in their study of a sufferer of agoraphobia, they say, "to broadly cover how the teller puts words together in sequences (syntax), how words themselves are structured (morphology), and the sound system (phonology) that speakers draw upon to make meaning" (Capps \& Ochs, 1995, p. 52).

The narrative life history of Butoyi (but this is largely valid for the other interviewees, too) provides examples of the colouring of their narration through specific language elements, elements that carry significant signs of interpretation and of meaning-making.

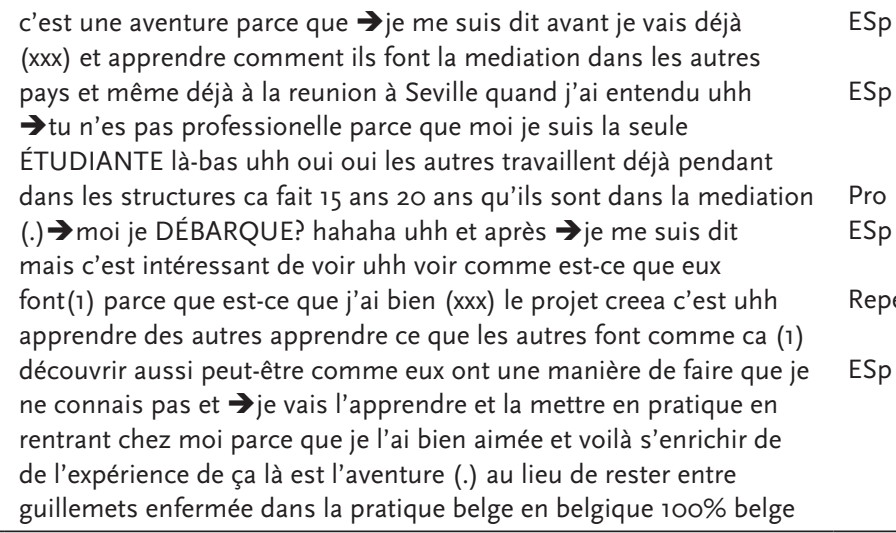

ESp
ESp
Pro
ESp
Repetition
ESp / Agency

Table 7: Extract 6

For Butoyi, her encounter with mediation and practising mediators on coming together with fellow colleagues at the start of the CreE-A project was "a shock". Putting what she has learnt into practice is a challenge, an adventure. She feels the need to emphasise her lack of experience. She is the only student among the project participants, 
she argues, and they have been practising mediation for decades already, while she is just 'setting out' ("moi je débarque"! I.6). The narrative in this extract is notably produced as first-person self-dialogue. We are asked to hear Butoyi's thinking at the particular point in the past when she made these experiences. The immediacy of the first-person voice lends veracity and authority to her argument, and at the same time obviates the necessity to account in detail for the position she takes up. This renders the narrative both authentic and self-oriented, believable yet uncontestable.

She continues, emphasising the greater impact of direct experience over reading and study. One learns from a book or from the internet, of course, but:

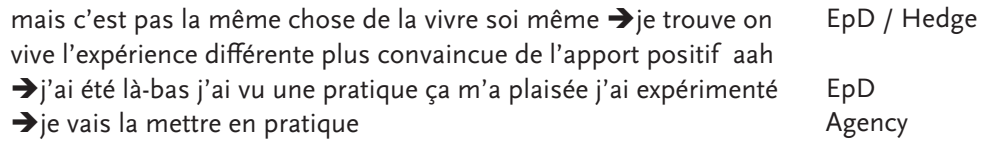

Table 8: Extract 7

While information, books, remain distant, the direct experience she has gained means she lives it "one hundred percent": "on la vit à 100 percent on est plus convaincue - je trouve". The shock she experienced at her first encounter with social mediation, however, was that doing mediation is difficult ("être médiateur n'est pas facile!").

\section{"BIOGRAPHICITY", AGENCY AND BIOGRAPHICAL REFLEXIVITY}

To be able to develop in talk a more coherent own narrative - in language terms to "translate" oneself - it is crucial to have access to learning spaces within which biographical resources can be acquired and deployed, and which, in turn, determine how experience and common sense are interpreted. "Biographicity", in Alheit's view (Alheit, 2006) stands for the drive or need (as well as the possibility) to draw on such resources of experience by exercising agency in the shaping of our lives. Gaston Pineau similarly underlines the essence of knowing how to live ("pouvoir-savoir vivre") and the difficulties involved for everyone in being agentic and in carrying forward the project of their lives. He states: "every being is a cogito, but at the same time crafting themselves, forming themselves only as well as they can" (Pineau, 1996, p. 78).

A biographic approach, then, which examines agentic identity as a resource drawn upon to make sense of learning experiences and, more simply, as Pineau suggests, in order to survive in the world (1996, p. 78) draws our attention as researchers and educational practitioners to what is taking place at the frontiers between lived life and reflected life, or "frontières biocognitives" in Pineau's words (1996, p. 78).

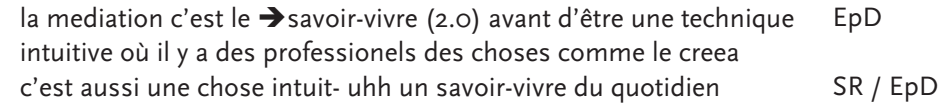

Table 9: Extract 8 
Butoyi expresses an idea very close to the notion of biographic learning employed by Gaston Pineau. The experience made in one or two schools in Belgium with mediation demonstrates, she feels, the nature of mediation as a "savoir-vivre", a process of sensibilization of school students that is, naturally, no easy matter ("ca prend du temps"). The collective experience of the trainee mediators and their trainers within the CreE-A project, in which family-type links could be forged, allows her to hope that the practical effects of mediation as a project, as a savoir-vivre may grow.

"Doing being" a "foreigner", a woman, a man takes places at the level of the "everyday", while biographical otherness, gender or class, for instance, must be conceived in a "lifetime" sense. Being a mediator, intervening in moments of conflict between strangers, people from entirely other life contexts, linguistic practices, behavioural uses - sharpens the process of producing agency at the borders of the everyday and the lifetime. Thus, as has already been observed (Silva et al., 2016, p. 94), the biographical construction of the mediator is both an act and a reflective process. As life developments continue in each new turn of the lived life, Bettina Dausien suggests, "new experiences are made which the subject is required to integrate in already existing self- and world-constructions, and as a result these are confirmed and stabilised (reproduction) or alternatively they must be 're-written' (transformation)" (Dausien, 1996, p. 574).

Butoyi recounts the difficulties experienced in her immersion phase of experience with experienced mediators, dealing with families and their daily problems of paying gas and electricity bills, keeping their flats, difficulties in understanding and being understood. The emotions are difficult to manage, but this is a path she has taken, an activity she has begun to try to be successful in. There are limits, however.

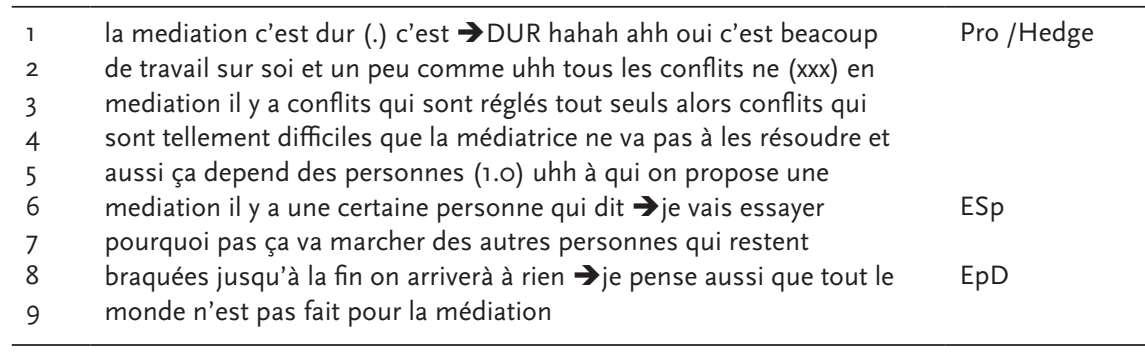

Table 10: Extract 9

Butoyi has to admit that the difficulties facing the mediator are not insignificant. Her insecurity on this topic can be heard in the prosodic effects of combined rise in volume and emphasis (Pro I.1) which she immediately "downgrades", so to speak. The laughter after the statement that mediation is hard may represent a move to self-defence after admitting possible weakness or inadequacy, it certainly represents a de-escalation of tension, a move to de-dramatize what might also appear to be overblown or unserious, for example. In any case, Butoyi's attempt to achieve co-understanding is tempered by the move to guard against criticism. The biographical narrative is always at risk of being misunderstood. Co-construction is the aim. It is not always the result. 
The biography is, then, constructed over life-time horizons and draws upon resources of experience, laid down in "layers" or "strata" which represent "reserves of sense or meaning" (Dausien, 1996). The biographical interview, allowing the telling of the changing life history, opens up a space, however, for reflection. Thus, Butoyi relates the shock of her first encounter with mediation practices in the field, she gives expression to her doubts and acknowledges the challenge mediation represents and offers glimpses of her biographical experience in connection with the practice as a mediator that have every component of a theory of an event (see Capps \& Ochs, 1995). The research context provides in fact the "stage" upon which biographical agency is related, "re-written" (metaphorically speaking), contextualised and constructed.

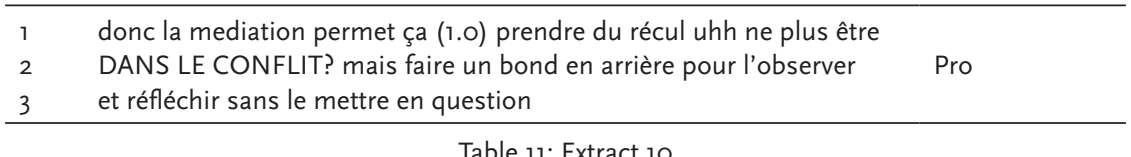

Table 11: Extract 10

Butoyi is able to draw the conclusion from the experience she has made in the community of practice represented by the period of time shared with the mediators participating with her in the CreE-A project, that she can in fact already see that she has a place in the field of social mediation.

\begin{tabular}{lll}
\hline 1 & moi je (.) cette année de spécialisation que j'ai faite et même surtout & \\
2 & le projet creea m'a premise de comprendre que VOILÀ au depart (.) & Pro \\
3 & au depart je me suis dit que je suis pas capable moi à résoudre les & ESp \\
4 & conflits des gens NON ça semblait impossible mais quand même & \\
5 & être médiatrice c'est une place que je (1.0) peux prendre & EpD /Agency \\
\hline
\end{tabular}

Tabel 12: Extract 11

She has come to understand that: "on doit se sentir capable".

\section{Conclusion}

Bourdieu has stressed the ways in which identity is performed through language use, and the way language in its own right is performed through "acts of identity", which allow us to understand the embodied production of language in each different social space as, in Bourdieu's words, "a dimension of an individual's physical hexis in which the social world in all its relationships and the world in all its socially instructed relationships are given expression". Language, he states, "is a technique of the body" embedded in all these social relationships (Bourdieu, 2001, p. 126).

With this in mind, I suggest that close attention to language in talk aids us to understand better the biographical narrative. A close examination of talk demonstrates, I argue, how language captures some of the following: 
- multiple contexts of interaction;

- the hedging and circumlocutions of the interview talk;

- the role of voice in narrative;

- $\quad$ memory and verbalisation of remembered space;

- the timbre of talk and the emotional and historical memory of people and institutions;

- $\quad$ assumptions of shared knowledge;

- tacit discourses of mutual understanding expressed in shared language use.

I suggest that the detail won in the kind of close analysis used here to discuss the narratives of a mediator is generalizable over the length of a complete biographical narrative. It is generalizable, too, to potential other narratives and talk of the same person(s). The analysis is documented and directly linked to the transcript. Linguistic evidence - language practices we can call them too - found in one part of a life-history will be findable and will be hearable elsewhere in that story, too.

The mediators who were interviewed, and the narrative of the mediator Butoyi, are on the edge of a significant experience, in the contexts of work, learning, social interaction, close personal and intellectual or emotional relationships. Mediation, as Helena Neves Almeida points out, presupposes knowledge, experience and professional abilities with the potential to transform personal, interindividual, social and community relationships, and to construct a more cohesive, peaceful, just and inclusive society (Almeida, 2016, p. 31). The role and professional identity of the present mediator and of possible future mediators in general is by nature dynamic, and is dependent on a labour of (self)-reconstruction and co-construction in action and interaction with others (Silva et al., 2016, p. 94).

In this understandably brief discussion of a selection of extracts from the biographical talk of a becoming-mediator, the local construction of social action/social meaningmaking can be heard. The construction of a professional savoir-faire is tentative, necessarily incomplete, audibly and in the transcript, I argue, visibly cautious, yet already explicit in the framing of new knowledge and new agency.

\section{REFERENCES}

Alheit, P. (1983). Alltagsleben. Zur Bedeutung eines gesellschaftlichen "Restphänomens". Frankfurt / New York: Campus Verlag.

Alheit, P. (1990). Biographizität als Projekt. Der "biographische Ansatz" in der Erwachsenenbildung (U. Bremen Ed.). Bremen: Universität Bremen.

Alheit, P. (2002). Biographieforschung und Erwachsenenbildung. In M. Kraul \& W. Marotzki (Eds.), Biographische Arbeit. Perspektiven erziehungswissenschaftlicher Biographieforschung (pp. 211-240). Opladen: Leske+Budrich. 
Alheit, P. (2006). ,Biografizität' als Schlüsselkompetenz in der Moderne Paper presented at the Universität Flensburg Tagung: „Das Leben gestalten. Biografisch lernen - biografisch lehren“, Universität Flensburg. Retrieved from http://www.abl-uni-goettingen.de/aktuell/Alheit_Biographizitaet_Schl-uessel_ Flensburg-2006.pdf

Alheit, P. (2018). The Concept of "Biographicity" as Background Concept of Lifelong Learning. Dyskursy mlodych andragogow, 19, 9-22.

Alheit, P. \& Dausien, B. (2002). Bildungsprozesse über die Lebensspanne und lebenslanges Lernen. In R. Tippelt (Ed.), Handbuch Bildungsforschung (pp. 565-585). Opladen: Leske + Budrich.

Almeida, H. N. (2016). Sustentabilidade da mediação social. Debates e desafios atuais. In A. M. C. Silva, M. d. L. Carvalho \& L. R. Oliveira (Eds.), Sustentabilidade da Mediação Social: Processos e Práticas (pp. 13-33). Braga: CECS. Retrieved from http://www.lasics.uminho.pt/ojs/index.php/cecs_ebooks/article/ view/2321/2237

Bertaux, D. (2005). L'enquête et ses méthodes. Le récit de vie. Paris: Armand Colin.

Bourdieu, P. (2001). Langage et pouvoir symbolique. Paris: Editions de Seuil.

Capps, L. \& Ochs, E. (1995). Constructing panic. The discourse of agoraphobia. Cambridge (MA): Harvard University Press.

Dausien, B. (1996). Biographie und Geschlecht. Opladen: Leske + Budrich.

De Fina, A., Schiffrin, D. \& Bamberg, M. (2006). Introduction. In A. De Fina, D. Schiffrin \& M. Bamberg (Eds.), Discourse and identity (pp. 1-23). Cambridge: Cambridge University Press.

Demetrio, D. (1995). Raccontarsi. L'autobiografia come cura di sé. Milano: Raffaello Cortina Editore.

Evans, R. (2004). Learning discourse. Learning Biographies, Embedded speech and Discourse Identity in Students' Talk. Frankfurt / Main: Peter Lang.

Fuchs-Heinritz, W. (2000). Biographische Forschung. Eine Einführung in Praxis und Methoden (2. ed.). Wiesbaden: Westdeutscher Verlag.

Goffman, E. (1981). Forms of talk. Oxford: Blackwell.

Gülich, E. \& Mondada, L. (2008). Konversationsanalyse. Eine Einführung am Beispiel des Französischen Romanistische Arbeitshefte, Vol. 52. Tübingen: Max Niemeyer Verlag.

Günthner, S. (1997). Complaint Stories. Constructing emotional reciprocity among women. In H. Kotthoff \& R. Wodak (Eds.), Communicating gender in context (Vol. 42, pp. 179-218). Amsterdam: John Benjamins.

Hoerning, E. M. (1989). Erfahrungen als biographische Ressourcen. In P. Alheit \& E. M. Hoerning (Eds.), Biographisches Wissen. Beiträge zu einer Theorie lebensgeschichtlicher Erfahrung (pp. 148-163). Frankfurt/ New York: Campus Verlag.

Hoffmann-Riem, C. (1994). Elementare Phänomene der Lebenssituation. Ausschnitte aus einem Jahrzehnt soziologischen Arbeitens. Weinheim: Deutscher Studien Verlag.

Linde, C. (1993). Life stories. The creation of coherence. New York /Oxford: Oxford University Press.

Luckmann, T. (1981). Lebenslauf und Sprache. In J. Matthes, A. Pfeifenberger \& M. Stosberg (Eds.), Biographie in handlungswissenschaftlicher Perspektive. Kolloquium am Sozialwissenschaftlichen Forschungszentrum der Universität Erlangen-Nürnberg (pp. 55-66). Nürnberg: Verlag der Nürnberger Forschungsvereinigung e.V. 
Merrill, B. \& West, L. (2009). Using biographical methods in social research. London: Sage.

Miller, G. (1994). Toward ethnographies of institutional discourse: proposals and suggestions. In G. Miller \& R. Dingwall (Eds.), Context and method in qualitative research (pp. 155-17). London: Sage.

Ochs, E. (1979). Transcription as theory. In E. Ochs \& B. B. Schieffelin (Eds.), Developmental pragmatics (pp. 43-72). New York: Academic Press.

Ochs, E. \& Capps, L. (2001). Living narrative. Creating lives in everyday storytelling. Cambridge (MA): Harvard University Press.

Pavlenko, A. (2007). Autobiographic narratives as data in Applied Linguistics. Applied Linguistics, 28(2), 163188. https://doi.org/10.1093/applin/ammoo8

Pineau, G. (1996). Les histoires de vie comme art formateur de l'existence. Pratiques de formations/Analyses, $31,65-80$.

Pineau, G. \& Le Grand, J.-L. (2007). Les histoires de vie. Paris: Presses Universitaires de France.

Ricoeur, P. (1995). Réflexion faite. Autobiographie intellectuelle. Paris: Editions Esprit.

Schegloff, E. A., Ochs, E. \& Thompson, S. A. (1996). Introduction. In E. Ochs, E. A. Schegloff \& S. A. Thompson (Eds.), Interaction and grammar (pp. 1-51). Cambridge: Cambridge University Press.

Schiffrin, D. (2006). From linguistic reference to social reality. In A. De Fina, D. Schiffrin \& M. Bamberg (Eds.), Discourse and identity (pp. 103-131). Cambridge: Cambridge University Press.

Schütze, F. (1975). Sprache soziologisch gesehen. Band II: Sprache als Indikator für egalitäre und nicht-egalitäre Sozialbeziehungen. München: Wilhelm Fink Verlag.

Schütze, F. (1976). Zur Hervorlockung und Analyse von Erzählungen thematisch relevanter Geschichten im Rahmen soziologischer Feldforschung. In Arbeitsgruppe Bielefelder Soziologen(Eds.), Kommunikative Sozialforschung (pp. 159-261). München: Wilhelm Fink Verlag.

Schütze, F. (1981). Prozeßstrukturen des Lebenslaufs. In J. Matthes, A. Pfeifenberger \& M. Stosberg (Eds.), Biographie in handlungswissenschaftlicher Perspektive. Kolloquium am Sozialwissenschaftlichen Forschungszentrum der Universität Erlangen-Nürnberg (pp. 67-157). Nürnberg: Verlag der Nürnberger Forschungsvereinigung e.V.

Silva, A. M. C., Carvalho, M. d. L. \& Aparicio, M. (2016). Formação, profissionalização e identidade dos mediadores sociais. In A. M. C. Silva, M. d. L. Carvalho \& L. R. Oliveira (Eds.), Sustentabilidade da Mediação Social: processos e práticas (pp. 93-104). Braga: CECS. Retrieved from http://www.lasics. uminho.pt/ojs/index.php/cecs_ebooks/article/view/2326/2242

Silva, A. M. C., Carvalho, M. d. L., Moisan, A. \& Fortecöef, C. (2017). Arlekin: a collaborative action-researchtraining project without frontiers. International Research Journal of Human Resources and Social Sciences, 4(3), 66-87. Retrieved from http://aarf.asia/hr2.php?p=Volume4,Issue3, March2017

Szczepek Reed, B. (2011). Analyzing conversation. An introduction to prosody. Basingstoke: Palgrave.

Tannen, D. (2007). Talking voices. Repetition, dialogue, and imagery in conversational discourse, Vol. 25. Cambridge: Cambridge University Press. 


\section{BIOGRAPHICAL NOTE}

Rob Evans, born in London, lives in Duisburg and has been a lecturer for Academic English/Business English at the Otto-von-Guericke-Universität Magdeburg, Germany since 2004. He studied Russian and History in Leeds and Tübingen. He has lived and worked outside the UK for over 40 years, in Germany, Italy and Egypt. His research interests are biography research methods and discourses of learning. He has edited books on the global/local world and adult learning $(2009,2010,2016)$, on biography research methods (2016), as well as collaborating as editor and reviewer for a number of European journals.

ORCID: 0000-0003-1168-4121

Email: rob.evans@ovgu.de

Address: Language Centre, English Department, Otto-von-Guericke-Universität Magdeburg, G40C-253 - Zschokkestr. 32, 39104 Magdeburg -Deutschland

* Submitted: 31/01/2019

$*$ Accepted: 04/03/2019 